\title{
PEMBESARAN LARVA IKAN GURAMI Osphronemus gourami SECARA INTENSIF DI SHEVA FISH BOYOLALI, JAWA TENGAH
}

\section{Intensive Rearing of Gouramy Osphronemus Gourami Larvae at Sheva Fish Boyolali, Central Java}

\author{
Naufal Abiyu Pratama ${ }^{1 *}$ dan Akhmad Taufiq Mukti². \\ ${ }^{1}$ Program Studi Budidaya Perairan, Fakultas Perikanan dan Kelautan, Universitas Airlangga, Surabaya \\ ${ }^{2}$ Departemen Manajemen Kesehatan Ikan dan Budidaya Perairan, Fakultas Perikanan dan Kelautan, Universitas \\ Airlangga, Surabaya \\ *naufal.abiyu.pratama-2015@fpk.unair.ac.id
}

\begin{abstract}
Abstrak
Tujuan Praktek Kerja Lapang (PKL) adalah mengetahui teknik pembesaran larva, manajemen pakan, kualitas air, pertumbuhan, perkembangan, kendala, dan permasalahan pada peembenihan ikan gurami secara intensif. PKL ini dilaksanakan pada 18 Desember 2017 sampai 18 Januari 2018 di Sheva Fish Kabupaten Boyolali, Jawa Tengah. Metode kerja yang digunakan adalah observasi dengan metode pengumpulan data secara primer dan skunder. Data diambil dengan cara observasi, wawancara, partisipasi aktif, dan studi pustaka. Pembesaran larva ikan gurami meliputi beberapa aspek, yaitu; sarana dan prasarana, persiapan kolam, penebaran benih, pemeliharaan benih, kualitas air, pakan, penanganan hama dan penyakit, serta panen. Wadah pemeliharaan yang digunakan adalah akuarium. Pakan yang digunakan adalah Tubifex sp. Parameter kualitas air meliputi parameter suhu (28-32 $\left.{ }^{\circ} \mathrm{C}\right)$, $\mathrm{pH}$ (7-8), oksigen terlarut (4,0-6,0 mg/l), dan amonia (0,0-4,0 mg/l). Pembesaran larva ikan gurami di Sheva Fish memakai sistem budidaya intensif dengan jangka waktu pemeliharaan 28 hari yang terdiri dari 8 hari pemeliharaan larva ikan gurami dan 20 hari pemeliharaan benih ikan gurami. Pakan diberikan setelah kuning telur pada larva habis secara ad libitum. Pemanenan dilakukan pada pagi atau sore hari untuk menghindari fluktuasi suhu. Persentase kelulushidupan pembesaran larva ikan gurami yang dianggap berhasil adalah 80-95 \%. Jumlah tebar pembesaran larva ikan gurami di Sheva Fish adalah 50.000 ekor dengan hasil pemanenan adalah 41.215 ekor, sehingga persentase kelulushidupan pembesaran larva ikan gurami adalah 82,43\%.
\end{abstract}

Kata kunci: Ikan Gurami, Pembesaran Larva and Sheva Fish Boyolali

Abstract

The purpose of Field Work Practices was to know the pattern of larvae rearing, feed management, water quality, growth, development, and problems on gouramy larvae rearing. The Field Work Practices held on 18 December 2017 to 18 January 2018 in Sheva Fish Boyolali District, Central Java. The working method were used was observation method with primary and secondary data collection. The data were taken with obervation, interview, active participation, and literature study methods. Gouramy larvae rearing includes several aspects: facilities and infrastructure, pond preparation, seed distribution, seed maintenance, water quality, feed, pest and disease management, and harvesting. Gouramy container was aquarium and the feed was Tubifex sp., the water quality parameters was temperature (28-32 $\left.{ }^{\circ} \mathrm{C}\right)$, $\mathrm{pH}$ (7-8), dissolved oxygen (4,0-6,0 mg/l), and ammonia (0,0$4,0 \mathrm{mg} / \mathrm{l})$. Intensive rearing of Gouramy larvae at Sheva Fish was done intensively with 28 days aquaculture consisting of 8 days larvae culture and 20 days seed culture. Feed given after egg yolks on larvae runs out with ad libitum methods. Harvesting was done in the morning or evening to overcome the temperature fluctuations. Survival rate of gouramy larvae rearing considered successful if the percentage was $80-95 \%$. The stocking density of intensive rearing of Gouramy larvae at Sheva Fish was 50,000 heads and harvested 41,215 heads with survival rate $82.43 \%$.

Keywords: Gouramy, Larvae Rearing and Sheva Fish Boyolali

\section{PENDAHULUAN}

Ikan gurami Osphronemus gouramy adalah salah satu jenis ikan air tawar yang banyak dipilih untuk dipelihara. Keunggulan ikan gurami adalah dapat berkembangbiak secara alami dan dapat hidup di air tergenang, kekurangan ikan gurami adalah pertumbuhannya 
lambat dengan rata-rata panen ukuran konsumsi dilakukan 6-12 bulan sekali. Habitat asli gurami yaitu terdapat pada rawa dataran rendah yang berair dalam. Ikan ini bersifat sangat peka terhadap suhu rendah dan memiliki organ pernapasan tambahan sehingga dapat mengambil oksigen dari luar air (Habibah, 2013).

Jumlah konsumsi ikan di indonesia dari tahun ke tahun semakin meningkat. Permintaan pasar ikan gurami cukup tinggi, tetapi hal ini tidak sejalan dengan kondisi produksi ikan gurami karena produksi ikan gurami tergolong tidak terlalu tinggi (KKP, 2014). Permintaan yang tinggi dapat dilihat dari statistik konsumsi ikan per kapita yang selalu meningkat. Konsumsi ikan per kapita pada tahun 2011 adalah 32,25 ikan/kapita, pada tahun 2012 meningkat menjadi 33,89 ikan/kapita (KKP, 2013), pada tahun 2013 meningkat menjadi 35,1 ikan/kapita, pada tahun 2014 meningkat menjadi 38,14 ikan/kapita, pada tahun 2015 meningkat menjadi 41,1 ikan/kapita, pada tahun 2016 meningkat menjadi 43,88 ikan/kapita, dan pada tahun 2017 mencapai angka 47,12 ikan/kapita (KKP, 2018).

Pembesaran larva diperlukan untuk meningkatkan produksi benih guna memenuhi permintaan pasar yang cukup tinggi. Pembesaran larva ikan gurami dibagi menjadi tiga sistem yaitu secara tradisional, semi-intensif, dan intensif. Pembesaran larva tradisional menggunakan kolam tanah dan padat tebar yang rendah, pembesaran larva semiintensif menggunakan kolam beton dengan dasar tanah dan padat tebar menengah, pembesaran larva intensif menggunakan kolam beton atau akuarium dan padat tebar yang tinggi. Pembesaran larva ikan gurami secara intensif adalah solusi untuk memenuhi permintaan pasar yang tinggi karena memiliki kelebihan pada jumlah padat tebar yang tinggi (Ulumiah, 2016).

Kegiatan yang dilakukan dalam pembesaran larva ikan gurami secara intensif meliputi persiapan kolam, pemeliharaan larva, pemeliharaan benih, dan pemanenan benih. Keterampilan dan pengetahuan baik dapat menunjang keberhasilan dalam usaha tersebut, sehingga diharapkan dapat meningkatkan kualitas dan produktifitas ikan gurami. Salah satu usaha yang dilakukan untuk memperoleh pengetahuan tersebut adalah melakukan Praktek Kerja Lapang (PKL) tentang pembesaran larva ikan gurami secara intensif di Sheva Fish Boyolali, Jawa Tengah.

Sheva Fish memiliki hatchery dengan komoditas ikan patin, ikan gurami dan ikan lele. Sheva Fish terdapat kegiatan pembenihan dan pendederan ikan patin, ikan lele, dan pembesaran larva ikan gurami. Pembesaran larva ikan gurami yang dilakukan di Sheva Fish dilakukan selama beberapa periode selama setahun. Pembesaran larva dilakukan berdasarkan permintaan pelanggan, jika benih sudah laku terjual sebelum masa pembesaran larva berakhir tidak akan ada kelanjutan kegiatan pembesaran larva dan akan membeli larva baru untuk dibenihkan kembali.

\section{METODOLOGI \\ Waktu dan Tempat}

Kegiatan PKL dilaksanakan di Sheva Fish, Desa Mojosari, Kecamatan Nogosari, Kabupaten Boyolali. Provinsi Jawa Tengah. Kegiatan PKL dilaksanakan mulai tanggal 18 Desember sampai 18 Januari 2018.

\section{Metode Penelitian}

Metode kerja yang digunakan dalam PKL ini adalah metode observasi. Observasi adalah pengambilan data dengan menggunakan indera mata tanpa ada pertolongan alat standar lain untuk keperluan (Nasution, 2011). Pelaksanaan observasi pada saat PKL adalah mengamati dan mengikuti semua kegiatan yang berhubungan dengan pembesaran larva ikan gurami secara intensif di Sheva Fish.

\section{HASIL DAN PEMBAHASAN}


Sheva Fish didirikan pada bulan Mei 2015. Sheva Fish memiliki unit usaha hatchery, pengiriman ikan, dan pelatihan pembenihan ikan. Chief executive Officer (CEO) Sheva Fish Boyolali mempunyai latar belakang jual beli online yang mengaharuskan beliau mempunyai hatchery untuk meyakinkan pembeli. Sheva Fish mempunyai 3 komoditas utama yakni, ikan gurami, ikan patin dan ikan lele. Komoditas yang diunggulkan di Sheva Fish yakni pembenihan dan pendederan ikan patin, serta pembesar ikan gurami.

Pembesaran larva terdiri atas fase pemijahan dan fase pendederan. Pendederan ikan gurami dibagi menjadi lima stadium. Pendederan pertama adalah pemeliharaan larva ukuran 0,75-1 cm dan pemeliharaan benih ukuran 1-2 cm. Pendederan kedua adalah pemeliharaan benih ukuran 2-4 cm. Pendederan ketiga adalah pemeliharaan benih ukuran 4-6 cm. Pendederan keempat adalah pemeliharaan benih ukuran 6-8 cm. Pendederan kelima adalah pemeliharaan benih ukuran $8-11 \mathrm{~cm}$ (SNI, 2000a). Pembesaran larva ikan gurami yang dilakukan di Sheva Fish adalah pembesaran larva larva dan pendederan pertama benih yang dibudidayakan di hatchery pada wadah pembenihan berupa akuarium berukuran $0,8 \times 0,8 \times 0,4 \mathrm{~m}$ dengan luas $0,64 \mathrm{~m}^{2}$ dan volume $0,256 \mathrm{~m}^{3}$.

\section{Persiapan Wadah}

Kegiatan persiapan kolam dilakukan untuk mendukung keberhasilan pembesaran larva dan pencegahan terjadinya penyakit (Sulistyo dkk., 2016). Pembesaran larva ikan gurami menggunakan akuarium sebagai wadah pemeliharaan. Sebelum dilakukan penebaran larva ikan gurami harus dilakukan persiapan wadah. Persiapan wadah dilakukan dengan enam tahap yaitu akuarium dibersihkan dari sisa air pemakaian sebelumnya, penyemprotan dinding dan dasar akuarium menggunakan klorin dengan dosis 3 gram/liter untuk 20 akuarium, pengeringan akuarium yang dilakukan selama 1-2 hari, pembilasan akuarium dari sisa residu klorin, pengisian air sampai ketinggian $20 \mathrm{~cm}$ dari dasar akuarium, dan meneteskan lima tetes methylene blue di setiap akuarium.

Proses persiapan wadah sebaiknya dilakukan secara urut karena dapat memutus rantai penyakit dari pemeliharaan sebelumnya apabila dilakukan dengan benar (Sulistyo dkk., 2016). Klorin berguna sebagai desinfektan yang mampu membunuh mikroorganisme merugikan yang masih menempel pada dinding dan dasar akuarium. Klorin membutuhkan waktu sekitar 1-2 hari untuk melakukan proses perusakan enzim pada mikroorganisme. Pembilasan klorin harus dilakukan karena klorin yang masih tersisa pada dinding akuarium dapat menyebabkan keracunan pada ikan dan terakumulasi dengan kandungan bahan organik pada air (Hasan, 2006).

\section{Penebaran Larva}

Penebaran larva ikan gurami dilakukan setelah persiapan kolam selesai dan dipastikan kondisi air stabil. Pemeliharaan larva dilakukan selama 8 hari dan dilanjutkan dengan proses pemeliharaan benih selama 20 hari. Larva ikan gurami berasal dari salah satu pembudidaya di purwokerto. Larva ditransportasikan pada sore hari dan sampai di Sheva Fish pada pukul 03.00 WIB. Transportasi pada sore hari dimaksudkan agar tidak terjadi fluktuasi suhu yang tinggi sehingga larva dapat bertahan hidup sampai masuk ke dalam akuarium. Larva yang akan dimasukkan ke dalam akuarium terlebih dahulu di aklimatisasi. Aklimatisasi adalah proses pemberian kesempatan pada ikan untuk menyesuaikan diri dengan lingkungan yang baru khususnya suhu dengan tujuan menghindari terjadinya stres pada larva yang akan ditebar di akuarium. Aklimatisasi dilakukan dengan cara menaruh larva ikan gurami yang masih ada di dalam plastik packing diatas air 
akuarium selama 20 menit, lalu dibuka dan ditebar. Sesuai dengan pendapat Effendi dkk. (2006) bahwa aklimatisasi dilakukan selama 20 menit karena suhu air plastik packing dan suhu air akuarium sudah tidak jauh berbeda.

Larva ikan gurami yang didatangkan terdapat 5 paket larva ikan gurami yang berisi sekitar 10.000 larva ikan gurami/paket, dalam 1 paket terdapat 3 plastik packing yang berisi sekitar 3.350 larva/plastik. Penebaran larva dilakukan dengan 2 sendok nasi/akuarium yang diestimasi terdapat 1.250 larva/sendok nasi. Paket terakhir tidak ditebar menggunakan sendok nasi, akan tetapi di hitung terlebih dahulu secara manual dengan menggunakan hand counter satupersatu untuk mengetahui jumlah larva dalam satu paket, sehingga dapat dilakukan penebaran larva dengan jumlah yang pasti dalam satu akuarium. Larva ikan gurami pada paket terakhir disebar pada 4 akuarium secara rata, sehingga dalam 1 akuarium berjumlah 2.500 ekor.

Larva yang ditebar pada akuarium masih terdapat kuning telur pada tubuhnya. Sesuai dengan pendapat Sulhi dkk. (2007) bahwa masa kritis larva adalah saat kuning telur mulai habis dan larva mulai mengambil pakan dari lingkungan. Pencarian pakan ditandai dengan larva mulai dapat berenang, sehingga harus mulai diberikan pakan karena apabila tidak diberi pakan akan menyebabkan larva kehabisan energi dan mengalami stres. Kuning telur larva ikan gurami akan habis pada hari ke 6-14 sejak menetas.

Larva ikan gurami berwarna kuning bening saat masih terdapat kuning telur dan berwarna abu-abu saat kuning telur sudah habis. Larva mati yang mengapung diambil dan dibuang menggunakan seser, larva mati yang tenggelam diambil dan dibuang menggunakan selang. Ciri-ciri larva ikan gurami mati yang masih memiliki kuning telur akan berwarna kuning keputihan dan ditumbuhi jamur apabila tidak segera diambil dan berwarna abu-abu pucat saat kuning telur sudah habis. Sesuai dengan pendapat Lucas dkk. (2015) bahwa Larva ikan gurami yang mengalami kematian harus dibuang setiap hari, karena apabila tidak dibuang akan menyebabkan timbulnya penyakit yang dikarenakan oleh jamur, bakteri, maupun parasit.

\section{Pakan}

Larva ikan gurami mulai diberi pakan setelah kuning telur pada larva habis, yaitu setelah 6-10 hari pemeliharaan. Sesuai dengan pendapat Herawati dan Agus (2014) bahwa pakan alami merupakan pakan awal utama bagi larva ikan gurami karena mempunyai kandungan nutrisi kompleks yang tidak dapat digantikan oleh pakan buatan. Pakan alami yang diberikan pada larva ikan gurami berupa Tubifex sp. karena memiliki pertumbuhan relatif, protein efesiensi rasio, efisiensi pemanfaatan pakan, dan kelulushidupan yang lebih baik dibanding pakan alami lain seperti Artemia sp. (Nugroho dkk., 2015), serta pakan buatan seperti kuning telur ayam dan pelet (Lucas dkk., 2015).

Tubifex sp. harus dicuci dari endapan lumpur dan kotoran sebelum diberikan ke larva, karena proses pencucian yang kurang bersih akan menyebabkan kualitas air pemeliharaan cepat menurun dan menimbulkan penyakit pada ikan. Tubifex sp. harus dicuci menggunakan antibiotik enrofloxacin dengan dosis $1 \mathrm{ml} / 3500$ gram cacing Tubifex sp. sebelum diberikan pada ikan.

Sesuai dengan pendapat Luturmas (2014) bahwa dosis optimal pemberian Enrofloxacin masih belum diketahui secara pasti dan berpotensi membuat bakteri resisten. Enrofloxacin diberikan pada pakan untuk mencegah terjadinya penyebaran bakteri patogen secara horizontal. Enrofloxacin dapat menghambat kerja enzim bakteri Pseudomonas aeruginosa, Klebsiella, Escherichia Coli, Enterobacter, Campylobacter, Shigella, Salmonella, Aeromonas, Haemophillus, Proteus, 
Yersinia, Serratia, Vibrio, Brucella, Chalamydia, Staphylocci mycoplasma, dan Mycobacterium.

Larva ikan gurami diberi pakan Tubifex sp. dengan sistem ad libitum yang berarti pemberian pakan sampai ikan kenyang, dosis pemberian pakan akan ditambah apabila pakan habis (Lucas dkk., 2015). Banyaknya pemberian pakan larva ikan gurami selalu menunjukkan grafik berkorelasi positif pada setiap harinya.

\section{Pengelolaan Kualitas Air}

Pengelolaan kualitas air merupakan faktor penting dalam kegiatan pembesaran larva ikan gurami. Pengelolaan kualitas air bertujuan untuk menyediakan lingkungan hidup yang optimal bagi benih ikan gurami untuk dapat hidup, berkembang, dan tumbuh sehingga bisa menunjang optimalisasi kelangsungan hidup dan pertumbuhan ikan gurami (SNI, 2000b). Pengamatan kualitas air meliputi parameter suhu yang diukur menggunakan termometer, $\mathrm{pH}$ yang diukur menggunakan kertas $\mathrm{pH}$, oksigen terlarut yang diukur menggunakan test kit oksigen terlarut, amonia diukur menggunakan test kit amonia. Pengamatan suhu dilakukan setiap hari, sementara $\mathrm{pH}$, oksigen terlarut, dan amonia diukur setiap minggu karena keterbatasan prasarana.

Pengelolaan kualitas air larva ikan gurami dilakukan secara rutin agar larva terhindar dari penyakit. Pengelolaan kualitas air dilakukan dengan melakukan pergantian air yang dilakukan 2 hari setelah pemberian pakan pertama. Pergantian air dilakukan setiap pagi dengan membuang 80\% air kotor pada akuarium, pembuangan air dilakukan dengan menyedot dasar akuarium agar kotoran yang mengendap di dasar akuarium dapat terangkat. Dinding akuarium sebaiknya digosok menggunakan spons sebelum pergantian air agar ganggang yang menempel pada kaca akuarium dapat ikut terbuang. Sesuai dengan pendapat Kusrini dkk. (2015) bahwa ganggang dapat menjadi perantara patogen berbahaya. Pengisian air sampai
$35 \mathrm{~cm}$ dari dasar akuarium dilakukan pada hari ke-14 karena sebagian besar larva ikan gurami sudah memasuki fase benih dan membutuhkan tempat pertumbuhan yang lebih besar (SNI, 2000b).

Suhu pemeliharaan larva ikan gurami yang optimal adalah 29-30 ${ }^{\circ} \mathrm{C}$ dan suhu pemeliharaan benih ikan gurami yang optimal adalah 25-30 ${ }^{\circ} \mathrm{C}$ (SNI, 2000b). Suhu pembesaran larva ikan gurami di Sheva Fish adalah $28-32{ }^{\circ} \mathrm{C}$. Sesuai dengan pendapat Hastuti (2005) bahwa perubahan suhu mencapai $4{ }^{\circ} \mathrm{C}$ tidak berpengaruh banyak pada ikan gurami karena ikan gurami akan mengalami stres apabila perubahan suhu mencapai $5{ }^{\circ} \mathrm{C}$ keatas. Pemeliharaan dari fase larva juga dapat mempengaruhi tingkat adaptasi sehingga dapat terbiasa dengan kualitas air yang tidak sesuai dari kualitas air optimal, tetapi dapat menyebabkan kematian apabila benih tidak dapat beradaptasi. Suhu air diatas angka optimal karena berlokasi di dataran rendah.

Oksigen terlarut membantu didalam proses oksidasi bahan buangan serta pembakaran makanan untuk menghasilkan energi bagi kehidupan dan pertumbuhan ikan gurami. Pengaruh menurunnya kadar oksigen terlarut dalam air dapat menyebabkan stres, anoreksia, hipoksia jaringan, pingsan bahkan kematian massal. Kadar oksigen terlarut pembesaran larva ikan gurami yang optimal adalah 4,0-7,1 mg/l (Sulistyo dkk., 2016). Kadar oksigen terlarut pembesaran larva ikan gurami di Sheva Fish adalah berkisar 4,0-6,0 mg/l. Kadar oksigen terlarut pada pembesaran larva di Sheva Fish masih berada pada taraf yang optimal untuk menunjang kelulushidupan serta laju pertumbuhan.

Amonia adalah hasil dari penguraian protein yang merupakan racun bagi ikan. Konsentrasi amonia dalam perairan dipengaruhi oleh kepadatan, pakan, $\mathrm{pH}$ dan suhu perairan. Pakan yang tersisa di perairan merupakan sumber nitrogen terbesar dalam budidaya yang dapat memacu pertambahan kadar amonia. 
Kadar amonia tinggi dapat menyebabkan naiknya kadar $\mathrm{pH}$ darah dan memiliki efek yang merugikan pada reaksi berbagai enzim dan stabilitas membran. Efek negatif tersebut meliputi kerusakan insang yang menyebabkan pengurangan kapasitas darah dalam membawa oksigen, serta kerusakan histologi pada sel darah merah. Tingginya kadar amonia dalam perairan akan menyebabkan terjadinya penurunan nafsu makan. Kadar amonia ikan gurami yang optimal adalah 0,0-0,12 $\mathrm{mg} / \mathrm{l}$ (Sulistyo dkk., 2016). Kadar amonia pembesaran larva ikan gurami di Sheva Fish adalah berkisar antara 0,0-4,0 mg/l. Sesuai dengan pendapat Hastuti (2005) bahwa tingginya kadar amonia pada pembesaran larva ikan gurami di Sheva Fish adalah karena padat tebar yang tinggi dan pemberian pakan secara ad libitum. Pemeliharaan dari fase larva dapat mempengaruhi tingkat adaptasi sehingga dapat terbiasa dengan kualitas air yang tidak sesuai dari kualitas air optimal, tetapi dapat menyebabkan kematian apabila benih tidak dapat beradaptasi dan diatas batas toleransi.

$$
\mathrm{pH} \text { berpengaruh terhadap }
$$

kelulushidupan dan laju pertumbuhan ikan. kelulushidupan dan laju pertumbuhan ikan dapat dipengaruhi $\mathrm{pH}$ karena nafsu makan dapat menurun saat $\mathrm{pH}$ rendah karena akifitas enzim pencernaan menjadi rendah dan terjadi penggumpalan lendir pada insang sehingga dapat menyebabkan kesulitan melakukan proses respirasi. Kadar $\mathrm{pH}$ pembesaran larva ikan gurami yang optimal adalah 6,5-8,0 (SNI, 2000b). Kadar $\mathrm{pH}$ pembesaran larva ikan gurami di Sheva Fish adalah berkisar antara 7-8. Kadar $\mathrm{pH}$ pada pembesaran larva di Sheva Fish masih berada pada taraf yang optimal untuk menunjang kelulushidupan serta laju pertumbuhan.

\section{Penyakit}

Terdapat dua tipe penyakit, penyakit infeksius dan penyakit non infeksius. Penyakit infeksius dapat berupa serangan virus, bakteri dan jamur.
Pencegahan penyakit infeksius pada benih ikan gurami dilakukan pada saat persiapan wadah dengan pemberian desinfektan dan antibiotik, serta pemberian antibiotik pada pakan. Penyakit non infeksius adalah penyakit yang tidak disebabkan oleh virus, jamur, dan bakteri, tetapi disebabkan karena faktor genetik, pakan, dan kondisi kualitas air buruk.

\section{Pemanenan}

Pemanenan di Sheva Fish dilakukan pada pagi atau sore hari sesuai dengan pendapat Sulhi dkk. (2007) bahwa pernyataan untuk menghindari fluktuasi suhu. Lama pemeliharaan tergantung pada faktor kesehatan benih dan ukuran pesanan. Panen pembesaran larva ikan gurami dilakukan dengan menggunakan seser yang kemudian menghitung benih satu-persatu untuk kebutuhan pengemasan dan perhitungan kelulushidupan dari satu siklus budidaya. Ikan saat pengemasan harus dihitung karena satu plastik packing harus berjumlah 600 ikan. Pemanenan ikan dilakukan dengan cepat dan hati-hati agar ikan tidak stres.

Pengangkutan ikan harus dikemas dengan menggunakan plastik yang diisi dengan oksigen secara tertutup. Transportasi ikan harus dilakukan dalam keadaan sejuk. Keadaan sejuk pada umumnya adalah pada pagi, sore, dan malam hari. Transportasi ikan harus mempertimbangkan lamanya waktu perjalanan yang akan ditempuh karena semakin padat jumlah ikan pada pengemasan dan pengangkutan dapat memperburuk kualitas air pada plastik packing, kualitas air yang buruk dapat mengakibatkan mortalitas pada benih (Sulhi dkk., 2007).

\section{Sampling}

Kelulushidupan dan laju pertumbuhan dapat diketahui dengan melakukan sampling. Sampling adalah proses pengambilan contoh secara representatif sehingga dapat mewakili seluruh populasi yang ada (Nasution, 
2003). Sampling panjang total tubuh benih ikan gurami dilakukan dari anterior mulut sampai posterior ekor menggunakan penggaris dengan ketelitian $0,1 \mathrm{~cm}$ dan bobot tubuh benih ikan gurami dengan menggunakan timbangan analitik dengan ketelitian 0,01 gram. Sampling dilakukan metode dari Lucas dkk. (2015) dengan pengambilan 3 ikan di setiap akuarium secara acak, sehingga didapatkan total 60 data sampling setiap minggunya.

Persentase kelulushidupan pembesaran larva ikan gurami yang dianggap berhasil adalah 80-95 \% (SNI, 2000b). Jumlah tebar pembesaran larva ikan gurami di Sheva Fish adalah 50.000 ekor dengan hasil panen 41.215 ekor, maka persentase kelulushidupan pembesaran larva ikan gurami selama 28 hari adalah 82,43\%. Faktor yang mempengaruhi laju pertumbuhan dan kelulushidupan ikan gurami diantaranya adalah kualitas benih, jenis pakan, kualitas air, dan penyakit.

Rerata panjang awal tubuh pembesaran larva ikan gurami adalah 0,875 $\mathrm{cm}$ dan rerata panjang tubuh akhir pembesaran larva ikan gurami adalah 2,36 $\mathrm{cm}$, maka pertumbuhan panjang mutlak pembesaran larva ikan gurami di Sheva Fish adalah 1,485 $\mathrm{cm}$ dengan pertumbuhan panjang nisbi $169,71 \%$.

\section{Analisa Usaha}

Pembesaran larva ikan gurami yang dilakukan di Sheva Fish memiliki jumlah produksi sebesar 41.215 ekor dengan harga jual Rp 200/ekor, sehingga biaya penerimaan diperoleh sebesar Rp 8.243.000 dalam satu siklus pembesaran larva. Nilai Revenue cost ratio pada pembesaran larva ikan gurami di Sheva Fish adalah 0,36. Nilai tersebut menunjukkan bahwa usaha ini kurang layak karena mengalami kerugian. Nilai Break event point harga pada pembesaran larva ikan gurami di Sheva Fish adalah Rp 43.091.975 dengan nilai Break event point produksi sebesar 212.014 ekor.

\section{KESIMPULAN DAN SARAN Kesimpulan}

Pembesaran larva ikan gurami di Sheva Fish memakai sistem budidaya intensif dengan jangka waktu pemeliharaan 28 hari yang terdiri dari 8 hari pemeliharaan larva ikan gurami dan 20 hari pemeliharaan benih ikan gurami. Pakan diberikan setelah kuning telur pada larva habis secara ad libitum yaitu pemberian pakan sampai ikan kenyang, dosis pemberian pakan akan ditambah apabila pakan habis. Pengelolaan kualitas air dilakukan pengurasan setiap hari pada pagi hari untuk memperbaiki kualitas air yang sudah turun dari kadar optimal. Pertumbuhan panjang dan berat berbanding lurus selalu meningkat.

Kendala yang terjadi di Sheva Fish adalah banyak terjadi kesalahan prosedur kerja karena pegawai sering melakukan percobaan, terkait dengan jumlah permintaan yang tinggi dan jumlah tenaga kerja yang terlalu sedikit sehingga pegawai Sheva Fish sudah terlalu lelah untuk melakukan prosedur kerja yang baik dan benar.

\section{Saran}

Sheva Fish memerlukan lebih banyak tenaga kerja terkait dengan jumlah permintaan yang tinggi dan jumlah tenaga kerja yang terlalu sedikit. Perlu dilakukan pelatihan pada pegawai untuk mengatasi permasalahan yang ada di Sheva Fish.

\section{DAFTAR PUSTAKA}

Effendi, I., H. J. Bugri, dan Widarnani. 2006. Pengaruh Padat Penebaran terhadap Kelangsungan Hidup dan Pertumbuhan Benih Ikan Gurami (Osphronemus gouramy Lac.) Ukuran $2 \mathrm{~cm}$. Jurnal Akuakultur Indonesia. Institut Pertanian Bogor. Bogor. 5 (2) : 127-135.

Habibah, R.. 2013. Pengaruh Komposisi Gulma Air Hydrilla (Hydrilla verticillata) dalam Ransum Ikan Gurami terhadap Pertumbuhan Ikan 
Gurami (Osphronemus gourami Lac). Jurnal Biologis. 1 (1) : 1-7

Hasan, A.. 2006. Dampak Penggunaan Klorin. Jurnal Teknologi Lingkungan. P3TL - BPPT. 7 (1) : 90-96.

Hastuti, S. 2005. Resistensi Stress Suhu Lingkungan dan Pertumbuhan Kompensasi Ikan Gurami (Osphronemus gouramy) yang Diberi Pakan dengan dan Tanpa Kromium Trivalen. Aquacultura Indonesiana. 6 (1) : 19-25.

Herawati, V. E. dan M. Agus. 2014. Analisis Pertumbuhan dan Kelulushidupan Larva Lele (Clarias gariepeanus) yang diberi Pakan Daphnia sp. Kultur Massal Menggunakan Pupuk organik Difermentasi. Jurnal Ilmu Pengetahuan dan Teknologi. 26 (1) : $1-11$.

Kementrian Kelautan dan Perikanan (KKP). 2013. Direktorat Jenderal Perikanan Budidaya. Data Statistik Tahunan Produksi Perikanan Budidaya.

Kementrian Kelautan dan Perikanan (KKP). 2014. Peraturan Menteri Kelautan dan Perikanan Republik Indonesia Nomor 35/PERMENKP/2014. 18 hal.

Kementrian Kelautan dan Perikanan (KKP). 2018. Direktorat Jenderal Perikanan Budidaya. Data Statistik Tahunan Produksi Perikanan Budidaya.

Kusrini, E., S. Cindelaras, dan A. B. Prasetio. 2015. Pengembangan Budidaya Ikan Hias Koi Cyprinus carpio Lokal di Balai Penelitian dan Pengembangan Budidaya Ikan Hias Depok. Media Akuakultur. 10 (2) : 71-78.

Lucas, W. G. F., O. J. Kalesaran, dan C. Lumenta. 2015. Pertumbuhan dan Kelangsunga Hidup Larva Gurami (Osphronemus gouramy) dengan Pemberian Beberapa Jenis Pakan.
Jurnal Budidaya Perairan. 3 (2) : 19-28.

Luturmas, A.. 2014. Pemberian Antibiotik Inroflox Terhadap Kelulus Hidup Benih Ikan Kerapu bebek Cromileptes altivelis yang Terinfeksi Bakteri Vibrio alginolitycus. Jurnal TRITON. 10 (2) : 79-84.

Nasution, R. 2003. Teknik Sampling. Fakultas Kesehatan Masyarakat. Universitas Sumatera Utara. 1-6 hal.

Nasution, S. 2011. Berbagai Pendekatan dalam Proses Belajar Mengajar. Bumi Aksara. Jakarta. 223 hal.

Nugroho, I. i, Subandiyono, V. E. Herawati. $2015 . \quad$ Tinkat Pemanfaatan Artemis sp. Beku, Artemia sp. Awetan, dan Cacing Sutera Untuk Pertumbuhan dan Kelangsungan Hidup Larva Gurami (Osphronemus gouramy, Lac.). Journal of Aquaculture Management and Technology. 4 (2) : 117-124.

Standard Nasional Indonesia (SNI). 2000a. Induk Ikan Gurame (Osphronemus gouramy, Lac) Kelas Induk Pokok (Parent Stock). SNI : 01-6485.12000. 1-7 hal.

Standard Nasional Indonesia (SNI). 2000b Produksi Benih Ikan Gurame (Osphronemus gouramy, Lac.) Kelas Benih Sebar. SNI : 016485.3-2000. 1-7 hal.

Sulhi, M., R. Samsudin, dan Hendra. 2011. Penggunaan Kombinasi Beragam Pakan Hijauan dan Pakan Komersial Terhadap Pertambahan Bobot Ikan Gurame (Osphronemus gouramy Lac.). Prosding Forum Inovasi Teknologi Akuakultur. 759-764 hal.

Sulistyo, J., Muarif, dan F. S. Mumpuni. 2016. Pertumbuhan dan Kelangsungan Hidup Benih Ikan Gurami (Osphronemus gouramy) pada Sistem Resirkulasi dengan Padat Tebar 5, 7, dan 9 Ekor/Liter. 
Jurnal Pertanian ISSN 2087-4936.

7 (2) : 87-93.

Ulumiah, M. 2016. Teknik Pembesaran

Ikan Bawal (Colossoma

macropomum) Secara Monokultur pada Kolam Semi Intensif di Balai Benih Ikan Puri Mojokerto. ADLN, Perpustakaan Universitas Airlangga. Fakultas Perikanan dan Kelautan. Universitas Airlangga.

Surabaya. 12-13 hal. 